\title{
Antibiotic activity of the extract of Punica granatum Linn. over bovine strains of Staphylococcus aureus
}

\author{
Maria A. R. Silva, ${ }^{1}$ Jane S. Higino, ${ }^{2}$ Jozinete V. Pereira, ${ }^{3} J^{\prime}$ sé P. Siqueira-Júnior, ${ }^{1}$ \\ Maria S. V. Pereira*,1 \\ ${ }^{1}$ Departamento de Biologia Molecular, Centro de Ciências Exatas e da Natureza, Universidade Federal da \\ Paraíba, 58051-970 João Pessoa-PB, Brasil, \\ ${ }^{2}$ Departamento de Farmácia, Centro de Ciências da Saúde, Universidade Federal de Pernambuco, Cidade \\ Universitária, 50740-521 Recife-PE, Brasil, \\ ${ }^{3}$ Departamento de Odontologia, Centro de Ciências Biológicas e da Saúde, Universidade Estadual da Paraíba, \\ 580100-000 Campina Grande-PB, Brasil
}

\begin{abstract}
RESUMO: "Atividade antimicrobiana do extrato de Punica granatum Linn. em linhagens de Staphylococcus aureus de origem bovina". A medicina humana e veterinária tem falhado no tratamento de infecções em longo prazo causadas por Staphylococcus aureus associadas ao desenvolvimento de resistência a agentes antimicrobianos. A atividade antimicrobiana do extrato da casca do fruto de Punica granatum Linn. foi avaliada sobre 38 linhagens de S. aureus de origem bovina para a determinação da concentração inibitória mínima (CIM). Das 38 linhagens ensaiadas, 22 são resistentes à penicilina.(PRSA). O extrato de $P$. granatum apresentou potencial ação antimicrobiana sobre todas as linhagens ensaiadas formando halos de inibição variando de 10 a $36 \mathrm{~mm}$ de diâmetro. Os resultados deste estudo confirmam a eficácia do extrato de $P$. granatum como potencial agente antibacteriano sobre $S$. aureus e demonstram a importância de se avaliar novas substâncias com potencial antimicrobiano, o que pode contribuir para a terapêutica alternativa em Medicina Veterinária.
\end{abstract}

Unitermos: Punica granatum, Punicacea, Staphylococcus aureus, atividade antimicrobiana.

\begin{abstract}
Human and veterinary medicines have not been so well succeeded in order to achieving their goals concerning the treatment of infections for long term caused by Staphylococcus aureus linked to resistance development against antibiotic agents. The antibiotic activity of the Punica granatum Linn. fresh fruit pericarp extract was evaluated by the agar diffusion method on $38 \mathrm{~S}$. aureus strains, isolated from apparently healthy lactating cows in farms situated in counties of the semi-arid region of the State of Paraíba, Brazil to determine the minimum inhibitory concentration (MIC). Twenty-two of the thirty-eight strains are penicillin-resistant (PRSA). The extract of $P$. granatum presented potential antibiotic action over all the assayed strains, forming 10 to $36 \mathrm{~mm}$ diameter inhibition zones. This paper's results claim the effectiveness of the extract of $P$. granatum as a potential antibacterial agent on $S$. aureus, and display the significance of evaluating new substances with antimicrobial potential, which can contribute to alternative therapeutics for veterinary and medicine.
\end{abstract}

Keywords: Punica granatum, Punicacea, Staphylococcus aureus, antibiotic activity.

\section{INTRODUCTION}

Staphylococcus aureus engenders a great deal of illnesses, from superficial injuries to severe systemic infections in man and other animals (Kloos \& Sheleifer, 1981). It is the greatest hospital pathogen, being described as significant etiological agent in hospital infections acquired since 1950; it is also the most usual microorganism associated to goatish and bovine mastitis (Harvey \& Gilmour, 1988; Watts, 1988; Shitandi \& Mwangi, 2004).

The antibiotic therapy is the most employed procedure in terms of treatment of bovine mastitis, nonetheless, the increasing concern about antibiotic residues in milk, and the appearance of resistant bacterium strains have been stimulating the search for alternative ways to decrease or eliminate such problems (Pinto et al., 2001). The abusive and indiscriminate use of antibiotic agents in both medical and veterinarian practice have a bottom-up effectiveness regarding the resistance of drugs arising and maintenance (Van Wamel et al., 1995; Gillespie \& Mchugh, 1997).

Plants with therapeutic properties have a great relevance in medicine throughout the world (Minja, 1994; Almeida et al., 2001; Silva et al., 2003; Rocha et al., 2005; Bezerra et al., 2006; Funke \& Melzig, 2006; 
Table 1. Minimum inhibitory concentration of the Punica granatum Linn. hydroalcoholic extract on 38 Staphylococcus aureus strains from bovine origin.

\begin{tabular}{|c|c|c|c|c|c|c|c|c|c|c|}
\hline \multirow{2}{*}{$\begin{array}{l}\text { Bacterial } \\
\text { strains }\end{array}$} & & \multicolumn{9}{|c|}{$\begin{array}{c}\text { Dilution of the extract } \\
\text { Inhibition zones diameter }(\mathrm{mm})\end{array}$} \\
\hline & $1: 0$ & $1: 1$ & $1: 2$ & $1: 4$ & $1: 8$ & $1: 16$ & $1: 32$ & $1: 64$ & $1: 128$ & $1: 256$ \\
\hline $102 \mathrm{U}$ & 26 & 25 & 23 & 20 & 19 & 17 & 15 & 13 & 12 & 10 \\
\hline $146 \mathrm{~L}$ & 30 & 29 & 27 & 24 & 23 & 20 & 18 & 15 & 13 & 00 \\
\hline $122 \mathrm{U}$ & 29 & 26 & 24 & 21 & 19 & 19 & 18 & 17 & 12 & 00 \\
\hline $203 \mathrm{FN}$ & 33 & 30 & 29 & 25 & 23 & 21 & 18 & 15 & 12 & 00 \\
\hline $204 \mathrm{U}$ & 34 & 32 & 30 & 28 & 24 & 18 & 16 & 14 & 12 & 00 \\
\hline $212 \mathrm{U}$ & 30 & 26 & 25 & 22 & 18 & 15 & 14 & 12 & 00 & 00 \\
\hline $215 \mathrm{FN}$ & 27 & 26 & 24 & 23 & 21 & 20 & 16 & 13 & 00 & 00 \\
\hline $224 \mathrm{FN}$ & 29 & 25 & 24 & 23 & 21 & 18 & 15 & 12 & 00 & 00 \\
\hline $226 \mathrm{U}$ & 29 & 26 & 22 & 19 & 17 & 15 & 13 & 12 & 00 & 00 \\
\hline $228 \mathrm{FN}$ & 30 & 29 & 28 & 25 & 23 & 20 & 16 & 13 & 00 & 00 \\
\hline $229 \mathrm{U}$ & 28 & 25 & 23 & 21 & 19 & 18 & 14 & 12 & 00 & 00 \\
\hline $230 \mathrm{FN}$ & 29 & 25 & 23 & 20 & 18 & 17 & 15 & 13 & 12 & 00 \\
\hline $233 \mathrm{FN}$ & 29 & 27 & 24 & 22 & 19 & 16 & 14 & 12 & 00 & 00 \\
\hline $235 \mathrm{U}$ & 24 & 21 & 18 & 17 & 16 & 15 & 13 & 11 & 00 & 00 \\
\hline $257 \mathrm{U}$ & 26 & 22 & 21 & 20 & 17 & 15 & 13 & 12 & 00 & 00 \\
\hline $302 \mathrm{U}$ & 33 & 31 & 29 & 26 & 22 & 19 & 16 & 13 & 11 & 00 \\
\hline $303 \mathrm{U}$ & 29 & 27 & 26 & 23 & 21 & 19 & 16 & 13 & 11 & 00 \\
\hline 304L & 27 & 23 & 19 & 17 & 15 & 13 & 12 & 00 & 00 & 00 \\
\hline $308 \mathrm{U}$ & 22 & 21 & 18 & 16 & 14 & 11 & 00 & 00 & 00 & 00 \\
\hline $309 \mathrm{U}$ & 25 & 22 & 18 & 16 & 15 & 15 & 15 & 12 & 11 & 00 \\
\hline $310 \mathrm{U}$ & 36 & 32 & 31 & 26 & 23 & 22 & 19 & 15 & 12 & 11 \\
\hline $311 \mathrm{FN}$ & 29 & 27 & 24 & 22 & 20 & 20 & 19 & 15 & 12 & 00 \\
\hline $311 \mathrm{~L}$ & 25 & 22 & 20 & 19 & 16 & 14 & 12 & 00 & 00 & 00 \\
\hline $311 \mathrm{U}$ & 25 & 23 & 21 & 19 & 17 & 15 & 13 & 11 & 00 & 00 \\
\hline $313 \mathrm{U}$ & 27 & 23 & 22 & 20 & 19 & 18 & 15 & 12 & 00 & 00 \\
\hline $311 \mathrm{FN}$ & 29 & 27 & 24 & 22 & 20 & 20 & 19 & 15 & 12 & 00 \\
\hline $313 \mathrm{FN}$ & 30 & 28 & 26 & 25 & 23 & 17 & 14 & 11 & 00 & 00 \\
\hline $314 \mathrm{FN}$ & 30 & 27 & 25 & 24 & 22 & 19 & 14 & 12 & 00 & 00 \\
\hline $316 \mathrm{U}$ & 29 & 25 & 24 & 23 & 21 & 18 & 16 & 14 & 12 & 00 \\
\hline $319 \mathrm{U}$ & 29 & 28 & 26 & 23 & 20 & 19 & 16 & 15 & 12 & 11 \\
\hline $324 \mathrm{U}$ & 31 & 29 & 27 & 25 & 24 & 19 & 16 & 14 & 12 & 00 \\
\hline \multicolumn{11}{|l|}{ PSSA } \\
\hline $114 \mathrm{U}$ & 30 & 29 & 27 & 25 & 22 & 21 & 18 & 15 & 12 & 11 \\
\hline $129 \mathrm{FN}$ & 26 & 24 & 22 & 21 & 19 & 17 & 15 & 12 & 0 & 00 \\
\hline $249 \mathrm{FN}$ & 24 & 21 & 20 & 19 & 18 & 15 & 13 & 11 & 0 & 00 \\
\hline $250 \mathrm{U}$ & 22 & 20 & 19 & 17 & 14 & 13 & 12 & 0 & 0 & 00 \\
\hline $322 \mathrm{FN}$ & 29 & 24 & 23 & 22 & 19 & 18 & 16 & 13 & 11 & 00 \\
\hline ATCC & 29 & 26 & 22 & 22 & 20 & 19 & 15 & 12 & 00 & 00 \\
\hline
\end{tabular}

PRSA = Penicillin resistant Staphylococcus aures; PSSA= Penicillin sensible Staphylococcus aureus.

Leitão et al., 2006; Lima et al., 2006; Barbosa-Filho et al., 2007; Rocha et al., 2007). Punica granatum Linn. belongs to the Punicacea family, and its fruit pomegranate - known as romã in Brazil - is great. It has a yellowish rind and dark spots, and contains seeds in its core. They are sweet and astringent (Moreira, 1978). This shrub is native of northeast India, and it is cultivated all over the world, in tropical and subtropical regions (Souza, 1991). In Northeast region of Brazil this plant have been used as gargling against infections and inflammations of the tract respiratory (Agra et al., 2007; Oliveira et al., 2007). Extracts of exocarpo of fruits have exhibited giardicidal activity (Amaral et al., 2006) and might be used as an effective antibacterial alternative agent against oral biofilm bacteria (Pereira et al., 2006).

The purpose of this survey is to determine the antibiotic activity of the Punica granatum Linn. Fresh fruit pericarp extract on bovine penicillin-resistant and -sensible S. aureus strains.

\section{MATERIAL AND METHODS}

\section{Preparation of the extract}

P. granatum Linn. raw material (pomegranate) was obtained in the Public Market of João Pessoa (Paraíba), and botanically identified at the Universidade Federal de Pernambuco. The extract was obtained from the fresh fruit pericarp of pomegranate (P. granatum) at the Laboratório de Toxicologia, Universidade Federal de Pernambuco. The fruits were separated into pericarp and mesocarp. The pericarp was the material used in the experiments. After drying in a greenhouse at 33 ${ }^{\circ} \mathrm{C}$, the material was ground and the active fraction extracted. The employed extraction method was the lixiviation or percolation in continuous flow at ambient 
temperature. The lixiviation, a process in which there is constant renewal of the extracting solution, was used (hydroalcoholic solution $95 \% \mathrm{v} / \mathrm{v}$ ). The procedure for the extract concentration was carried out in rotatory evaporator (Ika-Werk fashion), at a constant temperature of $45{ }^{\circ} \mathrm{C}$. The concentration at extract fluid level 1:1 $(\mathrm{p} / \mathrm{v})$.

\section{Bacterial strains}

The 38 strains of Staphylococcus aureus assayed were isolated from apparently healthy lactating cows in farms situated in counties of the semi-arid region of the State of Paraíba, Brazil (Pereira \& Siqueira-Júnior, 1995).

\section{RESULTS AND DISCUSSION}

\section{Antibiotic activity in vitro on $S$. aureus}

This paper's results show the effectiveness of the extract of pomegranate over all the assayed strains (Table 1). The antibacterial activity afforded an inhibition zone of 10 to $36 \mathrm{~mm}$. In accordance with the assayed plant's hydroalcoholic extract concentration, a homogenous growth inhibition was presented. There was a reduction of the inhibition zones diameter as the extract concentration was reduced, as displayed in table 1. The resistance to penicillin, in bovine samples of Staphylococcus aureus is a universal problem that persists since the 1950's (Wray, 1986); multiple resistance in bovine strains is not very frequent though. The assayed strains were previously characterized as for the resistance pattern. Resistance to penicillin was the most usual, followed by resistance to cadmium, streptomycin and tetracycline - antibiotics frequently used in the treatment of bovine infections. The results demonstrated an acclimation to environment pressures (Pereira \& Siqueira-Júnior, 1995).

Considering the resistance pattern for penicillin, the experimented strains were characterized as penicillinresistant $S$. aureus (PRSA) and penicillin-sensible $S$. aureus (PSSA). In the accomplishment of a comparative study with the extract of $P$. granatum, however, 16 of the 38 assayed strains $(42,1 \%)$ presented MIC at a 1:64 dilution; 13 samples $(34,2 \%)$ were inhibited at a $1: 128$ dilution, and 4 samples $(10,5 \%)$ were inhibited at a 1:256 dilution; 1 and 3 respectively presented MIC at 1:16 and 1:32 dilutions. Both PRSA and PSSA proved to be sensible to the extract.

The antibiotic activity of the extract of $P$. granatum is associated to tannin phytoconstituents and alkaloids, found in leaves, roots, stem and fruits (Nawwar et al., 1994; Souza, 1991; Machado et al., 2002).

The antibiotic activity of $P$. granatum was also observed by other authors on several microorganisms, including S. aureus (Anesine \& Perez, 1993; Lazo, 1990; Cáceres et al., 1987). Such data is congruous with our results. Michelin et al. (2005), however, observed that the $P$. granatum extract displayed no antibiotic activity on oxacillin resistant $S$. aureus.

The attained results verify the significance of gauging alternative and economically viable means to control infections in Veterinary medicine. In this context, it can be concluded that the extract of pomegranate has antibacterial activity in vitro, on PRSA and PSSA, which suggests the use of these substances in therapeutic indications in Veterinary medicine.

\section{REFERENCES}

Agra MF, França PF, Barbosa-Filho JM 2007. Synopsis of the plants known as medicinal and poisonous in Northeast of Brazil. Rev Bras Farmacogn 17: 114-140.

Almeida RN, Navarro DS, Barbosa-Filho JM 2001. Plants with central analgesic activity. Phytomedicine 8 : 310-322.

Amaral FMM, Ribeiro MNS, Barbosa-Filho JM, Reis AS, Nascimento FRF, Macedo RO 2006. Plants and chemical constituents with giardicidal activity. Rev Bras Farmacogn 16(Supl.): 696-720.

Anesine C, Perez C 1993. Screening of plants used in Argentine folk medicine for antimicrobial activity. $J$ Ethnopharmacol 39: 119-128.

Barbosa-Filho JM, Nascimento-Júnior FA, Tomaz ACA, Athayde-Filho PF, Silva MS, Cunha EVL, Souza MFV, Batista LM, Diniz MFFM 2007. Natural products with antileprotic activity. Rev Bras Farmacogn 17: 141-148.

Bezerra JL, Costa GC, Lopes TC, Carvalho ICDS, Patrício FJ, Sousa SM, Amaral FMM, Rebelo JMM, Guerra RNM, Ribeiro MNS, Nascimento FRF 2006. Avaliação da atividade leishmanicida in vitro de plantas medicinais. Rev Bras Farmacogn 16(Supl.): 631-637.

Cáceres A, Girón LM, Alvarado SR, Torres MF 1987. Screening of antimicrobial activity of plants popularly used in Guatemala for the treatment of dermatomucosal diseases. J Ethnopharmacol 20: 223-237.

Funke I, Melzig MF 2006. Traditionally used plants in diabetes therapy - phytotherapeutics as inhibitors of $\alpha$-amylase activity. Rev Bras Farmacogn 16: 1-5.

Gillespie SH, Mchugh TD 1997. The biological coast of antimicrobial resistance. Trends Microbiol 5: 337-338.

Harvey J, Gilmour A 1988. Isolation and characterization of staphylococci from goats liks produced in Northen Ireland. Lett Appl Microbiol 7: 79-82.

Kloos WE, Schleifer KH 1981. The genus Staphylococcus. In Starr MP, Stolp H, Truper HG, Ballows A \& Schelegel HG. The prokaryotes. Berlin Helberg Springer Verlag, 1548-1569.

Lazo W 1990. Accion antimicrobiana de algumas plantas de uso medicinal en Chile. Boletin Micológico 51: 25-28.

Leitão SG, Castro O, Fonseca EM, Julião LS, Tavares ES, Leo RRT, Vieira RC, Oliveira DR, Leitão GG, Martino 
V, Sulsen V, Barbosa YAG, Pinheiro DPG, Silva PEA, Teixeira DF, Lourenço MCS 2006. Screening of Central and South American plant extracts for antimycobacterial activity by the Alamar Blue test. Rev Bras Farmacogn 16: 6-11.

Lima MRF, Ximenes CPA, Luna JS, Sant'Ana AEG 2006. The antibiotic activity of some Brazilian medicinal plants. Rev Bras Farmacogn 16: 300-306.

Machado TB, Leal ICR, Amaral ACF, Santos KRN, Silva MG, Kuster RM 2002. Atimicrobial ellagitannin of Punica granatum fruits. J Braz Chem Soc 13: 606-610.

Michelin DC, Moreschi PE, Lima AC, Nascimento GGF, Paganelli MO, Chaud MV 2005. Avaliação da atividade antimicrbiana de extratos vegetais. Braz $J$ Pharmacogn 15: 316-320.

Minja MM 1994. Medicinal plants used in promotion of animal health in Tanzania. Rev Sci Tech 13: 905-925.

Moreira F 1978. As plantas que curam. São Paulo: Hemus.

Nawwar MAM, Hussein SAM, Merfort I 1994. Leaf phenolics of Punica granatum. Phytochemistry 37: 1175-11177.

Oliveira FQ, Gobira B, Guimarães C, Batista J, Barreto M, Souza M 2007. Espécies vegetais indicadas na odontologia. Rev Bras Farmacogn 17: 466-476.

Pereira MSV, Siqueira-Júnior JP 1995. Antimicrobial drug resistance in Staphylococcus aureus isolated from cattle in Brazil. Lett Appl Microbiol 20: 391-395.

Pereira JV, Pereira MSV, Sampaio FC, Sampaio MCC, Alves PM, Araújo CRF, Higino JS 2006. Efeito antibacteriano e antiaderente in vitro do extrato da Punica granatum Linn. sobre microrganismos do biofilme dental. Rev Bras Farmacogn 16: 88-93.

Pinto MS, Faria JE, Message D, Cassini STA, Pareira CS, Gioso MM 2001. Efeito de extratos de própolis verde sobre bactérias patogênicas isoladas do leite de vacas com mastite. Braz J Vet Res Anim Sci 38: 278-283.

Rocha LG, Almeida JRGS, Macedo RO, Barbosa-Filho JM 2005. Areview of natural products with antileishmanial activity. Phytomedicine 12: 514-535.

Rocha FD, Pereira RC, Kaplan MAC, Teixeira VL 2007. Produtos naturais de algas marinhas e seu potencial antioxidante. Rev Bras Farmacogn 17: 631-639.

Shitandi A, Mwangi M 2004. Occurrence of multiple antimicrobial resistance among Staphylococcus aureus Isolates from Kenyan milk. J Food Tech Afr 1: 23-25.

Silva JS, Moura MD, Oliveira RAG, Diniz MFFM, BarbosaFilho JM 2003. Natural products inhibitors of ovarian neoplasia. Phytomedicine 10: 221-232.

Souza MP 1991. Constituintes químicos ativos de plantas medicinais brasileiras. Fortaleza: Edições UFC/ Laboratório de Produtos Naturais.

Van Wamel WJB, Fluit AC, Wadstrom T, Van Dijk H, Verhoef J, Vandenbroucke-Grauls CMJE 1995. Phenotypic characterization pf epdemic versus sporadic strains of meticilin-resistant Staphylococcus aureus. J Clin Microbiol 33: 1769-1774.

Watts JL 1988. Etiological agents of bovine mastitis. Vet Microbiol 16: 41-66.

Wray C 1986. Some aspects of the ocurrenc of resistant bacteria in the animal flora. $J$ Antimicrob Chemother 18: 141-147. 